\title{
The Theory of the Global Domination - Russian Geo-Strategy Conceptual Framework on the Black Sea Region
}

\author{
Alba Iulia Catrinel Popescu ${ }^{1}$
}

\begin{abstract}
:
Russian geo-political maneuverings over the past decade can be explained in the context of the global domination theory, also known as the pivot theory.

Once the pivot theory is understood then strategies, tactics, and other actions being as wide as possible can be predicted.

What are the fundamental concepts of the pivot zone theory that marked out the strategic thinking of the last 100 years? What are the origins of Eurasian-ism and of neo-Eurasianism? Which are the current geostrategic directions of the Russian Federation? Which are the tactics applied by the Kremlin? Those are some of the questions analyzed in this article.
\end{abstract}

Keywords: Global domination, the Northern pivot zone, North-South strategic corridor, the Black Sea-Baltic Sea isthmus, Black Sea region, security ring, Gerasimov doctrine.

\footnotetext{
${ }^{1}$ National Defense University “CAROL I”, albatanasescu@hotmail.com
} 


\section{Introduction}

British geo-strategist, Sir Halford J. Mackinder (1861-1947) defined the Northern pivot zone (aka the Northern Heartland) as the vast area located in Eurasia, bounded on the east by the Yenisei River, on the west by the Black Sea-Baltic Sea Isthmus, on the north by the Siberian forests and on the south by the Central Asian deserts. It is a crossroad connecting the Northern hemisphere to the Southern hemisphere, the West to the East, an area extremely rich in resources from which attacks can be launched and which can be attacked from all directions. It is now occupied by the Russian Federation and its satellite states from Central Asia and Eastern Europe ${ }^{2}$.

Based on these characteristics of the pivot zone, Mackinder postulated that the power controlling Eastern Europe controls the pivot zone, the power that controls the pivot zone controls the ,island of the world" (the continental mass made by Europe, Asia and Africa) and, whoever controls the ,island of the world" controls the world. ${ }^{3}$ Appropriately, the pivot zone theory is also known as the theory of the world domination.

At the same time, Mackinder pointed the strategic importance of the area located in the close proximity to the pivot zone for her protection or, on the contrary, her blocking. This area, in the shape of a ring, consisting of the Arctic ice, the Baltic states, the Black Sea-Baltic Sea isthmus, the lower and middle segments of the Danube, and the Danube Delta, the Black Sea, Asia Minor, Armenia, Persia (Iran), Tibet and Mongolia ${ }^{4}$, is vital for the security of the power that controls the pivot zone. It is defined as the pivot zone security ring. The pivot zone is then surrounded by the Eurasian coastal area, called the inner crescent, and another outer insular crescent (Figure 1). Also Mackinder pointed to the Arabian Peninsula, described as a interpivotal zone, linking the Northern pivot zone (Eurasian) and the Southern one $\left(\right.$ sub-Saharan $^{5}$ ), where Syria has a geographic position of utmost strategic importance, as it ensures the control of land routes connecting Eurasia and Africa.

Twenty years after McKinder's theory, American geostrategyst John Nicholas Spykman (1893-1943), nicknamed the ,father of the damming policy”, developed the maritime correlative of Mackinder's theory emphasizing the strategic importance of the Eurasian coasts, defined as the Rimland, corresponding to the inside semicircle that surrounds the pivot zone (Figure 2).

\footnotetext{
${ }^{2}$ Russian Federation's satellite states are Kazakhstan, Turkmenistan, Uzbekistan, Tajikistan, Kirgizstan, Belarus and Ukraine.

${ }^{3}$ Halford J. Mackinder, Democratic Ideals and Reality: A Study in the Politics of Reconstruction, National Defense University Press, Washington D.C., copyright $₫$ 1942, Constable Publishers, London, p. 106.

${ }^{4}$ Halford J. Mackinder, Democratic Ideals and Reality: A Study in the Politics of Reconstruction, Idem, op. cit., p. 78.

${ }^{5}$ Halford J. Mackinder, Democratic Ideals and Reality: A Study in the Politics of Reconstruction, Idem, op. cit., p. 60.
} 
Figure 1: The geographical pivot of history $(1904)^{6}$

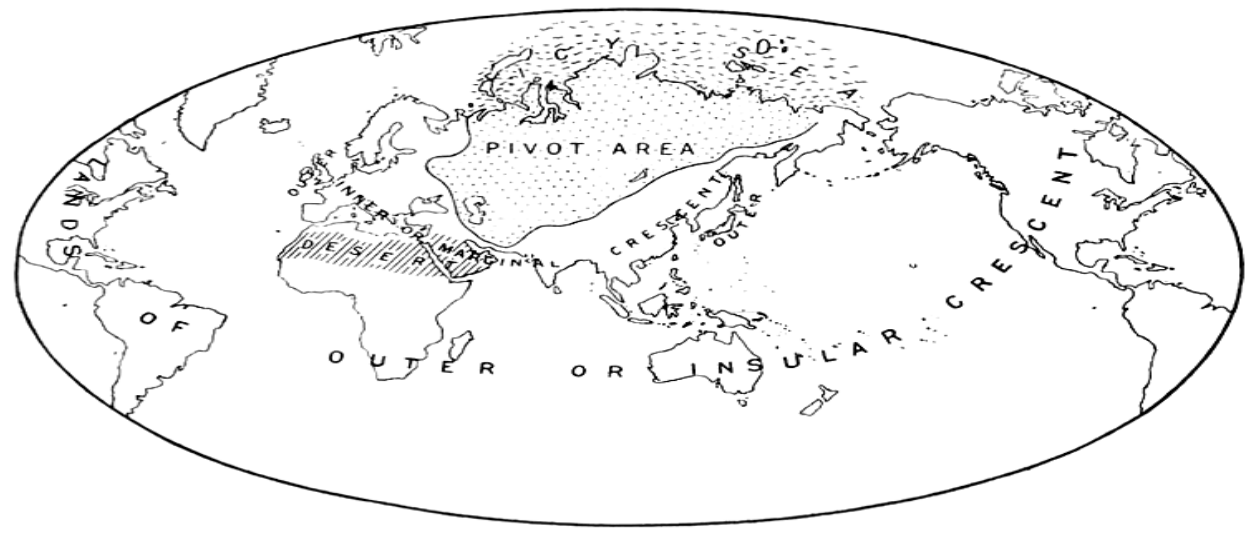

Figure 2: The ,Rimland” theory ${ }^{7}$

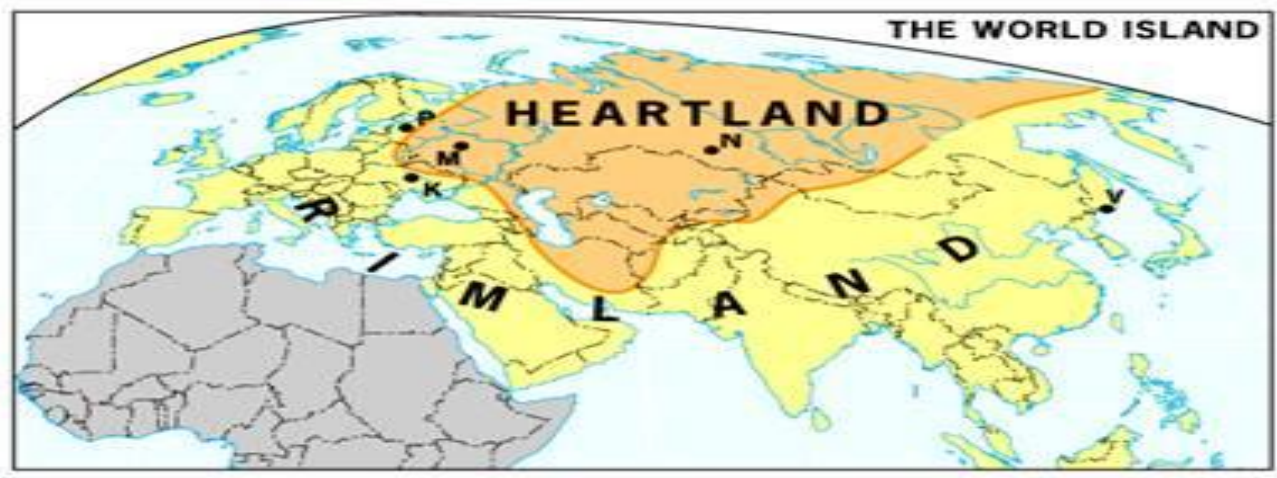

In Spykman's view, Rimland is the buffer area separating the pivot zone and the maritime „highway” that surrounds Eurasia, consisting of „Europe, Persia (Iran) plus concept arguing that domination of the shores will be critical to contain the power that rules the pivot area and the power that will control the Eurasian Rimland will be able, finally, to dominate the world ${ }^{8}$. Therefore, the US will be forced by all means to prevent the emergence of a European or an Asian hegemon that could master the Eurasian shores.

\footnotetext{
${ }^{6}$ Halford J. Mackinder, The Geographical Pivot of History, The Geographical Journal, No.4, April 1904,

Vol.XXIII,http://intersci.ss.uci.edu/wiki/eBooks/Articles/1904\%20HEARTLAND\%20THEOR Y\%20HALFORD\%20MACKINDER.pdf, accessed at 20.07.2015, p.435

${ }^{7}$ http://teacherweb.ftl.pinecrest.edu/snyderd/mwh/ap/apgeographers.htm, accessed at 29.07.2015

${ }^{8}$ Nicholas J. Spykman, The Geography of the Peace, Idem. op. cit., p. 44.
} 
Contemporaneous of Spykman, on the other side of the Atlantic, geopolitician Karl Haushofer (1869-1946) developed the pivot zone theory from the German perspective, formulating among other concepts, incluindg global panregionalization. According to pan-regionalization the world is ordered in four economic pivot zones „Grosswirtschafträume” namely Germanic Western Europe, Russia, Japan and the US. Each one of these economic pivot zones represents a panregion. Russia was to master the Northern pivot zone and its adjacent areas in the Far East, Central Asia, the Middle East and the Black Sea basin. Germany would revert to absolute control of ,pan-Eurabia” and pan - Eur - Afrika consisting of Western Europe, Africa, the Middle East and the Arabian Peninsula9 (Figure 3).

Figure 3: Haushofer's global pan-regional dividing ${ }^{10}$

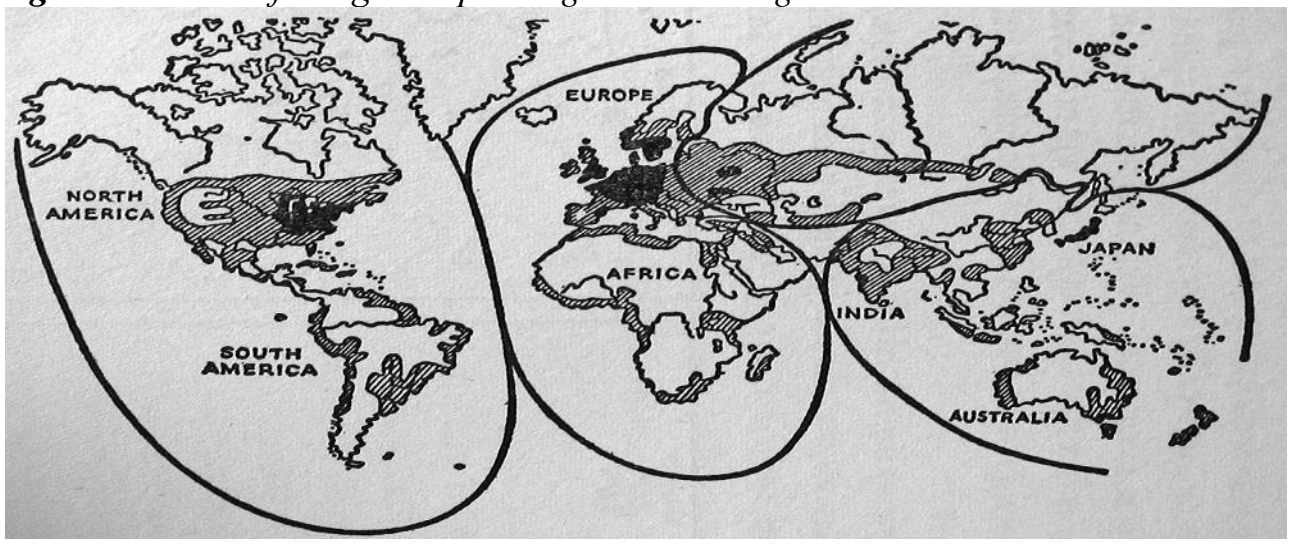

Later, between 1980-1990, American geopolitician Saul Cohen, author of the theory of global spaces, referred to the Eurasian coastal area as the „compression zone" which he described as a highly fragmented area, due to the pressure of the geopolitical neighborhood that may have, according to the level of the geopolitical dynamism, a ,gateway" character (a portal of trade, military, demographic flows), a „shatterbelt" (ruin) character or a „convergence zones” character (of a „region caught between geopolitical areas whose status is still uncertain ${ }^{11}$ "). By ,shatterbelt" Cohen described geopolitically fragmented, unstable areas with great geostrategic importance, either in terms of the strategic resources, or in terms of the geographical location. The geostrategic stakes adjacent to the "shatterbelts" generate a fierce

\footnotetext{
${ }^{9}$ Eric Ross, of heartlands and pan-regions: mapping the spheres of influence of the great powers in the age of world wars, March 5, 2015, https://ericrossacademic.wordpress.com/2015/03/05/of-heartlands-and-pan-regionsmapping-the-spheres-of-influence-of-the-great-powers-in-the-age-of-world-wars/, accessed at 29.07.2015.

${ }^{10}$ Eric Ross, Of heartlands and pan-regions: mapping the spheres of influence of the great powers in the age of world wars, Idem. op. cit.

${ }^{11}$ Saul Bernard Cohen, Geopolitics: The Geography of International Relations, Third Edition, Rowman \& Little field Publishing Group Inc., USA, 2015, p.37
} 
competition for their control, involving the two global areas, the maritime and continental one. As Cohen defined them, the „,convergence” zones correspond to the pivot zone security ring described by Mackinder. In the area of convergence, Middle East and sub-Saharan Africa are the current two „shatterbelts" 12 and the Eastern Europe qualifies for the ,gateway” status.

In 2000, the American geopolitician Zbigniew K. Brzezinski, author of the geostrategic pivot theory, fragmented Eurasia into four areas. According to Brzezinski the Northern pivot zone and the Far East comprise the middle space around which are arranged three areas of the inner crescent: the Eastern area of the Indian peninsula, the Southern area of the Middle East and the Near East and the Western Europe area located at West side from of the Black Sea-Baltic Sea isthmus (Figure 4). Brzezinski classified the Eurasian states in active geostrategic players, side powers and geostrategic pivots (among which includes Iran).

Figure 4: Eurasian chess table $e^{13}$

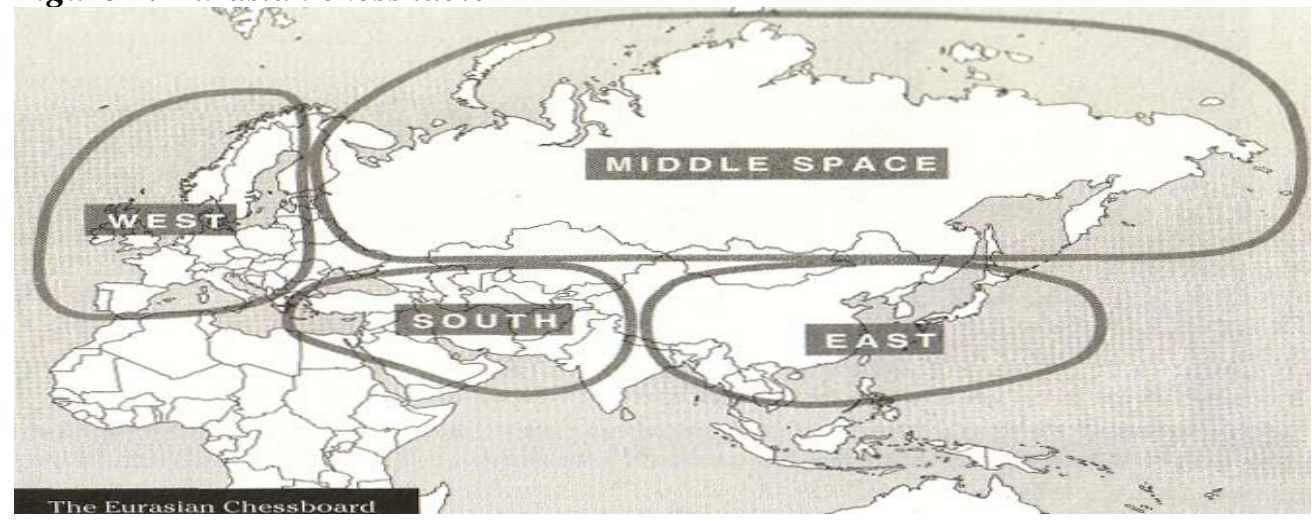

In France, Frédéric Encel adapted the pivot zone theory to his country's national interests, focusing on the former French colonial empire ${ }^{14}$; and the Canadian geopolitician (of Greek origin) Dimitri Kitsikis expanded the Northern pivot zone, which he called ,the interim”, to include the Sahelian belt. He achieved this by adding the Arab - Saharan interpivot zone and Northern Africa to the Northern Pivot Zone emphasizing „interim"'s major geostrategic importance for the global domination.

In mid - May 2016, the American journalist Robert D. Kaplan launched in Bucharest several books dedicated to the strategic analysis of Eurasia. One of them,

\footnotetext{
${ }^{12}$ Saul Bernard Cohen, Geopolitics: The Geography of International Relations, Idem. op. cit., p. 44.

${ }^{13}$ Zbigniew Brzezinski, The Grand Chessboard: American Primacy and its Geostrategic Imperatives, BasicBooks, 1997, http://www.takeoverworld.info/Grand_Chessboard.pdf, accesat la data de 29.07.2015, p. 34.

${ }^{14}$ Frédéric Encel, Orizonturi geopolitice, Editura Cartier, Bucuresti, 2011, p. 174.
} 
titled "The Revenge of Geography. What the Map Tells Us About Coming Conflicts and the Battle Against Fate"15, brings to the fore the geographical connection of the geopolitical processes, the matrix of any geostrategic analysis. In fact, Kaplan's recent approach joins the strategic analyzes with the starting point into the paradigm of world domination.

\section{What is Eurasian - ism? What is neo-Eurasian - ism?}

Eurasian-ism, the Russian exile interwar doctrine, was "nurtured" by the pivot zone theory and the theory of pan - ideas and pan - regions representing these theories as adjusted to Russian geopolitical interests. Exceeding the pan-orthodox, messianic, regional vision, which legitimized the tsarist expansionism, Eurasian-ism offered a pan-continental perspective for Russian ambitions. Prince Nikolai Sergeyevich Trubetzkoy (1890 -1938), "the father" of the Eurasian-ism doctrine, published in 1920 a paper entitled "Europe and humanity" where he dissassociated Russian culture from European culture of Roman and Germanic origin which he accused infests Russia and hides a form of cultural subjugation ${ }^{16}$.

Russian historian and anthropologist Lev Nikolaevich Gumilyov (1912-1992), the author of the ethno genesis theory ${ }^{17}$ according to which the development of the ethnic groups pass through similar steps (birth, development, climax, inertia, flounder and memory), advocated for the Eurasian over-ethnos to replace a strictly Russian ethnos and that would thus scientifically explain embedding the non Russian peoples into the Soviet "mixer". Also, Gumilyov argued as to Russia civilization's special identity resulting from the synthesis of the Turk-Mongol steppe peoples with Slavs, and to its civilizing role in Eurasia. Gradually, Eurasian-ism was shared by representatives of the Russian cultural elite who have promoted its three cardinal ideas of this doctrine, namely:

1. Russian culture and civilization are neither European nor Asian but have mixed Slavic - Turanian features;

2. Orthodoxy is a civilizing factor;

3. The empire is the state system that folds neatly to the Russian ethnos.

Although obscured by communist-internationalist speech, the Eurasian "idea cracy" (a concept formulated by Trubetzkoy, which is semantically equivalent to the

\footnotetext{
${ }^{15}$ Robert D. Kaplan, Razbunarea Geografiei. Ce ne spune harta despre conflictele viitoare si lupta impotriva destinului, Editura Litera, Bucuresti, 2016.

${ }^{16}$ Martin A. Schwartz, De La Ginghis Han La Ideocrație. Viziunea Eurasianistă a Lui Nikolai Trubețkoi, Eurasia: Rivista Di Studi Geopolitici, 18 Iulie 2014, http://www.eurasiarivista.org/de-la-ginghis-han-la-ideocratie-viziunea-eurasianista-a-lui-nikolaitrubetkoi/21749/, accessed at 29.07.2015.

${ }^{17}$ Lev Gumilev, Ethnogenesis and the Biosphere,

http://gumilevica.kulichki.net/English/ebe1.htm, accessed at 29.07.2015, chapters 2, 3.
} 
48

pan - idea), grounded the Soviet political construction and subsequently reaffirmed the Russian Federation as the legitimate heir to the USSR.

In 1990, the Russian geo-politician Aleksandr Gelievich Dughin resumed the Eurasian - ism theses applied at the Eurasian continental mass, which he amalgamated with conceptual elements belonging to the theory of the global domination, theory of the global space and of the Nomos world, as well as with the theses of the civilization war, into a theory known as neo-Eurasian-ism. Taking an ideologically tortuous route, from communism in the Soviet period, to the national Bolshevism (hybrid - Right doctrine placed between fascism and Bolshevism) in the immediately subsequent USSR implosion period, Dughin becomes, in 2000, the "fourth political theory" (also known as postmodern conservatism) theoretician (the post modern conservatism is regarded as a counterweight to the cosmopolitan and the globalized neoliberal - ism).

In 1997, Aleksandr Dugin published a book, "The basis of geopolitics and Russia's geopolitical future" 18 , where he formulated the main guidelines of neo - Eurasian ism, namely:

$\checkmark$ The existence of a perpetual confrontation between the "thalasso" - cracy dominated by the US and the maritime powers and the "teluro" - cracy dominated by the continental powers led by Russia;

$\checkmark$ Russia's imperial destiny as the Eurasia's hegemonic power that rules between the Levant and the Pacific;

$\checkmark$ The construction of a system of alliances based on the common rejection of the „Atlantic” - ism, neoliberal - ism and unipolarity, ment to support Russian political and economic domination of the world.

In this regard, Dughin identifies four vital geostrategic axis:

$\checkmark$ The anti-American continental axis Moscow - Berlin - Paris ${ }^{19}$;

$\checkmark$ Moscow - Tehran axis, which secures the Caucasus, offers to Russia strategic control of the Persian Gulf region and Central Asia, and is "the fundamental basis of the Eurasian geopolitical project"20;

$\checkmark$ Moscow - Berlin axis which blocks the penetration of American influence in the former satellite states of Eastern Europe;

\footnotetext{
${ }^{18}$ Aleksandr Dughin, Osnovy geopolitiki: Geopoliticheskoe budushchee Rossii, Bol'shoe prostranstvo, Moscow: 'Arktogeya', 1997; varianta romaneasca Aleksandr Dughin, Bazele geopoliticii și viitorul geopolitic al Rusiei, Editura Eurasiatica, București, 2011.

${ }^{19}$ Charles Clover, Will the Russian Bear Roar Again? Financial Times, 2 December 2000, http://eurasia.com.ru/eng/ft.html, accessed at 02.08.2015.

${ }^{20}$ Aleksandr Dughin, Bazele geopoliticii și viitorul geopolitic al Rusiei , Editura Eurasiatica, București, 2011, p. 164.
} 
$\checkmark$ Moscow - Tokyo axis meant to counterbalance China's growing influence in the Asia - Pacific region.

The ultimate goal of these alliances is the „birth" of the "empire of several empires" 21 led by Russia:

$\checkmark$ A bipolar international system, which opposes the Eurasian empire to Washington-London marine axis, structured into global spaces based on the Huntingtonian civilization model connected through power relationships. Inside this bipolar system, there is a "multi-polarity" of empires that makes up the great Eurasian confederative empire. In Dughin's opinion, Eurasia is structured into global spaces (characterized by common racial, religious, geopolitical and political features), namely: European German empire, Russian empire, Central Asia empire dominated by Iran, the Pacific empire dominated by Japan and four autonomous areas: the Hindu world, the Chinese world, the Arab world (Southern Muslim empire or the Caliphate), and the Pan-African Union ${ }^{22}$;

$\checkmark$ Awareness of the danger posed by globalization will determine the union between the Heartland and the Rimland, and Russia will gain access to warm seas ${ }^{23}$;

$\checkmark$ The building of the Pan-Arab Caliphate, in fact the coagulation of the Northern African and the Arabian Peninsula states - the first step toward building Euro-Africa which transforms the Mediterranean Sea into an "internal lake" and offers absolute control of the sub-Saharan Africa. The vectors of this process will be Libya, Palestine and Iraq, countries with openly anti-American orientation, that will „neutralize” the Saudi Arabia. The coordinator of the operation will be the German-led European empire ${ }^{24}$;

$\checkmark$ Both the strategic axis with Iran followed by the building of the Central Asian empire and the pan - Arab Caliphate aim at isolating and encircling Turkey and taking full control of the Black Sea basin by the Russian Federation $^{25}$.

Dughin's strategic vision of the Eurasian "empire" is shared by Sergei Alexandrovich Karaganov, the current foreign policy adviser to the Russian Federation President, Vladimir Vladimirovich Putin, and, also, dean of the School of International Economics and Foreign Policy in Moscow. Even if his approach differs from that of Dughin concerning the messianic component, in substance, the two visions are converging. Thus, Karaganov's strategy in Eurasia replaces the "confederative empire" with a Union of a Europe "that would stretch from Lisbon to

\footnotetext{
${ }^{21}$ Aleksandr Dughin, Idem, op. cit., p. 116.

${ }^{22}$ Aleksandr Dughin, Idem, op. cit., pp. 165-166.

${ }^{23}$ Aleksandr Dughin, Idem, op. cit., p. 118.

${ }^{24}$ Aleksandr Dughin, Idem, op. cit., p. 165.

${ }^{25}$ Aleksandr Dughin, Idem, op. cit., p. 163.
} 
Vladivostok, a huge area of free trade and free movement", a union that combines European Union's soft power with Russia's hard-power and resources ${ }^{26}$. The new Union' of Europe's security would be guaranteed by a Collective Security Treaty signed by states and organizations - Eurasian Economic Union EEU, the Organization of the Collective Security Treaty and NATO. Also, the states that would refuse the integration into this "union" would be left outside, suffering economic, political, military consequences and the specter of these consequences will solve "the gray areas" issue (such as Turkey, Moldova, Ukraine and Georgia ${ }^{27}$ ).

Or, in other words, the building up of a Eurasian de - globalized and de globalizing "teluro" - cracy, would be released from the US and the UK "thalasso" cracy supremacy. Also, Karaganov, the author of the doctrine that bears his name, supports both Russia's Eastern pivoting in order to strengthen the partnerships with the Asian countries (integration of the Eurasian Economic Union with the Chinese "Belt and Road Initiative", where China has a leading role but not a hegemonic $\mathrm{one}^{28}$ ), and the use of ethnic Russians in states that are located in the Russian Federation's "immediate vicinity" as vectors for keeping these regions in Moscow's sphere of influence.

The short presentation of these geopolitical theories belonging to Anglo - Saxon and the Russian schools are obviously convergent on the following elements:

$\checkmark$ Geo - determined approach aimed to control the security ring of the Northern pivot zone, a necessary but not sufficient condition for the AfricanEurasian continental mass control;

$\checkmark$ A common conceptual origin of the mentioned geostrategic theories, coming from the theory of the global domination that demonstrates the durability of the directions set by Mackinder's geostrategic analysis;

$\checkmark$ The major impact of the pivot zone paradigm upon the foreign policy of the main two geostrategic players, active in the wider Black Sea region (USA and Russia);

$\checkmark$ The pan - Eurasian imperial vision of the Russian Federation's strategic thinking schools.

\section{What are the Russian Federation's current geostrategic directions in the Black Sea region?}

\footnotetext{
${ }^{26}$ Matei Dobrovie, Celălalt ideolog al lui Putin. Arma minorităţilor. Amestecul China-Rusia, trotil geopolitic,

The Epoch Times Romania, 04.04.2014, http://epochtimes-romania.com/news/celalaltideolog-al-lui-putin-si-arma-minoritatilor---215310, accessed at 07.07.2016.

${ }^{27}$ Sergei Karaganov, Eurasian Way Out of the European Crisis, 07.06.2015, RUSSIA IN GLOBAL AFFAIRS, http://eng.globalaffairs.ru/pubcol/Eurasian-Way-Out-of-the-European-Crisis-17505, accessed at 07.07.2016.

${ }^{28}$ Sergei Karaganov, Idem. Op. cit.
} 
Based on the global domination paradigm, the Russian Federation's current main geostrategic directions aim at preserving the exclusive control its own security ring (of the Northern pivot zone) by:

$\checkmark$ Pushing the facto border (the advanced line of defense) at the internal frontier of the Russian security space, following the line made by: Kaliningrad, Moldavia (Transnistria), Ukraine (Crimea, Donbas, Luhansk), Georgia (Abkhazia, Adjaria, South Ossetia), Kazakhstan, Turkmenistan, Uzbekistan, Tajikistan, Kyrgyzstan;

$\checkmark$ Maintaining the Caucasian (made up of Georgia, Azerbaijan, Armenia) and Central Asian (comprised of former Soviet republics Kazakhstan, Turkmenistan, Uzbekistan, Tajikistan, Kyrgyzstan) security area in its exclusive sphere of influence;

$\checkmark$ Transformation and maintaining the nearby security areas made up of the trans-European North - South corridor (Finland, Sweden and the perimeter for the Arctic, the Baltic states, Poland, Hungary, Slovakia, Romania, Bulgaria, Serbia, FYROM, Greece, Cyprus), as well as Iran, Afghanistan Mongolia into buffer zones;

$\checkmark$ Switching the key geostrategic players attention from the issues related to the Russian Federation's security ring by initiating/maintaining/escalation of geopolitical processes away from this area but with impact upon regional and/or global power equation (e.g. Syrian conflict, the emergence of the radical Islam, the Libyan conflict, the wave of illegal border migration, the deepening of the Islamic sectarian war Sunna / Shi'a);

$\checkmark$ Gathering the anti-unipolarity forces into institutional formulas like BRICS or the Shanghai Cooperation Organization aimed at becoming future centers of hegemonic power;

$\checkmark$ Breaking up Euro-Atlantic cohesion both at the EU level and within NATO by maintaining privileged relations (economic, political, diplomatic) with "key" strategic partners, such as Germany, France, Italy, and Spain or pro Russian "Trojan Horses" seen as Greece, Cyprus, Hungary, and Slovakia;

$\checkmark$ The initiation and/or maintenance of geostrategic tensions between the major geostrategic players acting in the vicinity of the security ring: the US, China, India, the EU (Germany, France, the UK) or between geostrategic players and some regional powers (the US - Iran, the US - Turkey, the US Israel, Turkey - Israel, the US - the EU, the US - Germany, the US France, the US - China, China - India, the US - Saudi Arabia etc) and the use of these political, economical, financial, military divergences in Russia's own interest;

$\checkmark$ Restoring the former Soviet sphere of influence through hybrid instruments that amalgamate smart - power economic, political, diplomatic, military, technological, cultural, ideological, propaganda tools.

In this regard, we can identify the following active geo-strategic axes:

1. Moscow - Berlin - Paris; 
2. Moscow - Belgrade - Athens - Nicosia - (Sofia);

3. Moscow - Yerevan - Tehran;

4. Moscow - Ankara - Tehran;

5. Moscow - Tehran - Damascus (Beirut, Gaza);

6. Moscow - Tehran - Dushanbe - Ishmaelite communities of Central Asia.

The European Axis Moscow - Berlin - Paris is based on a series of common interests: privileged bilateral economic partnerships, joint geostrategic affiliation to the continental mass, historic competition with the maritime powers (the US and the UK), hegemonic aspirations announced by attempts to rebuild the former sphere of influence through smart-power strategies (Germany in the Mittel-Europe, Russia in Eastern Europe, France in the former French colonial empire).

It became visible since 2008 when France and Germany blocked the NATO Membership Action Plan for Ukraine and Georgia at NATO Summit in Bucharest. Subsequently, the French - Russian - German troika acted in order to manage the Ukrainian crisis in Russia's favor by accepting the rebel groups to negotiate Minsk agreements or by blocking Occidental offensive armament aid for Ukraine. Moreover, the current German foreign minister, Frank - Walter Steinmeier, criticized NATO's "aggressive" approach toward Russia ${ }^{29}$ and the French President - in - Office, François Hollande has advocated at the NATO Summit in Warsaw in July 2016 that the Russian Federation is not a threat although "she is able sometimes, as we have seen in Ukraine, to use force" ${ }^{\text {"30 }}$.

France was supposed to sell to Russia, had the Ukrainian crisis not interferred, two amphibious assault Mistral-class ships, one of which was meant to join the Black Sea naval forces (Sevastopol ship ${ }^{31}$ ), despite NATO allied states objections, including Romania, who warned about the strategic impact of such a transaction.

This Axis is strengthened by the involvement of other EU countries known for their skeptical attitude towards the US presence in Europe, with different degrees of economic and energy dependence towards Russia, such as Italy, Spain, Hungary, Czech Republic and Slovakia.

\footnotetext{
${ }^{29}$ Justin Huggler, German foreign minister accuses NATO of 'warmongering' against Russia, The Telegraph, 18.06.2016, http://www.telegraph.co.uk/news/2016/06/18/german-foreignminister-accuses-nato-of-warmongering-against-rus/, accessed at 07.07.2016. ${ }^{30}$ Hollande: Russia Is A Partner, Not A Threat, Radio Free Europe, 08.07.2016, http://www.rferl.org/content/hollande-russia-is-a-partner-not-a-threat/27847690.html, accessed at 21.07.2016.

${ }^{31}$ Jean - Sebastien Evrard, Russia Egypt \$1B Mistral Deal: Warships' Helicopters, Equipment Agreed on After France Sale, Kremlin Says, Agency France - Presse, 19.10.2015, http://www.ibtimes.com/russia-egypt-1b-mistral-deal-warships-helicopters-equipmentagreed-after-france-sale-2146777, accessed at 07.07.2016.
} 
The Orthodox Axis Moscow - Belgrade - Athens - Nicosia (Sofia) is consolidated around common Orthodox Christian affiliations, strained relations with the West consistent bilateral economic relations, dependence of these countries on Russian gas, a positive common history. For example, the Greeks are unhappy with inconsistent responses by NATO allies toward the Cyprus conflict, the effects on the domestic economic front from the austerity policies imposed by the EU and Germany, and internal consequences of EU policy regarding illegal migration. The Serbs are still resentful from recent episodes of open conflict with the West.

Cyprus has granted Russian military and commercial ships "indefinite" maritime anchorage in Limassol port facilities ${ }^{32}$. This agreement, which has turned Limassol in a de facto Russian naval base, should be seen in conjunction with the existing Russian military base in the Syrian port of Tartus, located at $241 \mathrm{~km}$ from Limassol, as the combination facilitates Russian military control of the Mediterranean Levantine Basin.

On the other hand, Greece is a historical partner of Russia in the region, and currently, the Prime Minister in office, Alexis Tsipras, is close to the Kremlin's circles of power. In their bilateral relations with Serbia, Greece and Cyprus have not recognized the independence of the Serbian province of Kosovo and refused to participate in NATO's military operations against Serbia in 1999. Today, under the economic sanctions imposed by Moscow on EU commercial transactions, Serbia brokers Greek and Cypriot exports to Russia. In Niš, Serbia, the airport, located at $100 \mathrm{~km}$ from the Kosovo border, operates a regional Russian-Serbian humanitarian center $^{33}$ suspected of hiding a military base meant to spy on the US/NATO military base at Deveselu, in Romania.

Moreover, the strategic Serbia - Greece - Cyprus triangle facilitates Russian strategic influence within the Balkans, an extremely important geopolitical area in terms of energy economic and military corridors. This axis is occasionally joined by Bulgaria, a "captive state", due to her energy and economic dependence on Russia. Bulgaria's recent refusal to support Romania's efforts to set up a NATO naval group in the Black Sea ${ }^{34}$ is part of a series of "Trojan Horse" interventions within the Western bloc.

\footnotetext{
${ }^{32}$ Paul J. Saunders, Russia Pulse: Cyprus port deal gives Russian navy alternative to Tartus, AL MONITOR, 03.03.2015, http://www.al-monitor.com/pulse/originals/2015/03/russiasanctions-europe-nato-economy-cyprus-mediterranean.html\#, accessed at 20.08.2015.

${ }^{33}$ Russia opens 'humanitarian' base in Serbia, EurActiv, 18.10.2011, http://www.euractiv.com/section/global-europe/news/russia-opens-humanitarian-base-inserbial, accessed at 07.07.2016.

${ }^{34}$ Cătălina Mihai, Bulgaria refuză să participe la flota comună NATO la Marea Neagră, o iniţiativă lansată de România, EurActiv, 16.06.2016, http://www.euractiv.ro/extern/bulgariarefuza-sa-participe-la-flota-comuna-nato-la-marea-neagra-o-initiativa-lansata-de-romania4691, accessed at 07.07.2016.
} 
The Caucasian Axis Moscow - Yerevan - Tehran is consolidated around the commercial and strategic partnership that jointly counteracts the Turkish (and subsequenty Azeri) influence in the Caucasus and the Central Asia, as well as Georgia's "pro - Western" atitude. This axis provides Russian geostrategic control of the Caucasus, considered the intersection of the North - South and East - West Eurasian geopolitical axes, and of the Russian Federation's Eastern Black Sea security ring expressed by:

$\checkmark$ trade and energy corridors;

$\checkmark$ the Russian military base in Gyumri, Armenia ( Military Base No.102 belonging to the Russian Forces in the Transcaucasia Group);

$\checkmark$ military, economic and political support given to Armenia by the Russian Federation in the context of Azerbaijan - Armenia frozen conflict over Nagorno - Karabakh;

$\checkmark$ close military cooperation between Russia and Iran.

From the geostrategic point of view, Iran is the pivot that provides the entrance into the Russian inner security ring, through geopolitical axes that effect in Central Asia, Levant and Middle East.

The Moscow - Ankara - Tehran Axis is consolidated around common trade and energy corridors, is backed by ideological disagreements and by competition for the leading role inside the Islamic world among Saudi Arabia on one side, and Iran and Turkey on the other, as well as the fears of a US - backed independent Kurdish state at the Turkish-Iranian border.

This potential Kurdish state, established in the territory historically occupied by Kurds in Syria and Iraq, a potential American bridgehead in the Middle East, should be seen in conjunction with Israel, the US strategic ally in the Levantine area. An Israel - Kurdistan - Washington potential axis would break up the Turkish-Iranian monolith in the region and a US military base located in Kurdistan would serve for the Western strategic control of the Middle East, in conjunction with US military bases in Djibouti (Horn of Africa) and in Afghanistan (South Asia). (This axis could be seen in tandem with another potential geopolitical axis Washington - territory occupied by Tuaregs (South of Libya/North of Mali), designed to secure the median Sahel belt region and to ensure the control of the rich oil deposits and strategic minerals ores within this area.)

The Moscow - Ankara ${ }^{35}$ Axis, although strained by competition over controlling Turkic populations in Central Asia, the Caucasus and Iran, and by the domination of the historical Bosphorus and Dardanele Straits problem that has proven effective in situations such as the Georgian crisis of 2008, or in the "smoldering" wars in

\footnotetext{
${ }^{35}$ As I already mentioned, in Dughin's opinion, one of Russian Federation's strategic goals is
} Turkey extraction from the Euro-Atlantic sphere of influence. 
Ukraine and Syria, when Turkey "played a game" that ended up serving Russian interests. The recent Russian-Turkish incident at the Syrian border, when a Russian warplane was shot down by a Turkish one, has sharpened the divisions between the two regional powers but the common energy and trade interests and especially the bilateral strategic imperative of blocking of a future Kurdish state in the region have led to the rebuilding of the relationship ${ }^{36}$.

On the other hand, Iran is Russia's strategic partner in the Middle East, is also one of Turkey's traditional economic partners, with whom it shares common anti-Saudi views in the Islamic Cooperation Organization, both countries aiming to assume the role of leader of the Islamic world.

The Shi'a Axis Moscow - Tehran - Damascus (Beirut, Gaza) is vital to Russian interests as it provides the access to warm oceans as witnessed by the Russian military bases in Tartus and Latakia, Syria, and by military cooperation with Iran, it also provides the mainenance of Russian influence in the Eurasian inter-pivot zone, counterbalance of the Turkish neo-Ottomanism, the Saudi Wahhabism, and counterbalance to Western influence in the Middle East, especially in the context of the Israeli-Arab conflict.

Operational since 1971 - the year when the Shi'a Alawi President Hafez al Assad seized the power in Syria. The axis was reinforced after 1979 - the year of the Islamic Revolution in Iran that radically changed the power configuration in the Middle East and sub-Saharan Africa. The US lost of Iran as an ally increased Saudi Arabia's geostrategic value to Washington.

Conseqeuntly, Saudi Arabia became the main US ally in the Gulf region despite its Wahhabi and Salafi radical, ultraconservative form of Islam, eminating from the Hanbali Legal Islamic School ${ }^{37}$ promoted by Riyadh. The theocratic regime in Tehran, supported by the Soviet Union and later by the Russian Federation, became the driver of Shi'a Islam in the Gulf region, directly or through the Hezbollah Islamist organization which is active in Lebanon, and through the Shi'a populations in Yemen, manafest in the Houthi rebels, as well as in Bahrain, Iraq, and Saudi Arabia.

\footnotetext{
${ }^{36}$ Tudor Martalogu, Kremlin: Erdogan i-a prezentat lui Putin scuze pentru doborârea avionului militar rus, Agerpres, 27.06.2016, http://www.agerpres.ro/externe/2016/06/27/kremlin-erdogan-i-a-prezentat-lui-putin-scuzepentru-doborarea-avionului-militar-rus-16-42-51, accessed at 07.07.2016.

${ }^{37}$ The Hanbal Legal School, founded by the Islamic cleric Musnad Imam Ahmad bin Hanbal (780-855) completely rejects reflection, claiming the strict application of the Koran and tradition.
} 
Between the Syrian Alawi regime and the Iranian theocracy there are other elements that strengthen bilateral relations such as belonging to the same Shi'a Islamic denomination, and the historical positive politico-diplomatic, economic and military relationship with Moscow. While Iran is the geostrategic pivot that breaks up Russian Federation's inner security ring, Syria is the "hinge State" that tips the geostrategic balance of region. Moreover, the Damascus regime has acted in Lebanon through a military occupation of 29 years, and in the Gaza Strip through the Islamist Organization Hamas which is supported by Russian and Syrian intelligence.

The Tehran-Damascus Axis has acquired critical value for Moscow with the discovery, in December 2010, of a 3.454 billion cubic meter gas field, called "the Leviathan", located in the Levantine Mediterranean basin, and which is disputed between Israel, Lebanon Syria, Gaza and Cyprus. The discovery of "the Leviathan" added geo-economic value to the imperative geo-strategic control of the region, since the exploitation and the transportation of the Levantine gas in Europe could reduce EU energy dependence on Russian gas, a tool Moscow has used to gain political leverage in the EU.

Thus, maintaining the political control over "Leviathan" riparian states became one of Moscow's most important foreign policy objectives. With the exception of Israel, all other aforementioned countries have been traditionally within the Russian sphere of influence. In this context, the refusal of the Syrian President Bashar al Assad to engage his country in the construction of the Qatar - Turkey gas pipeline which was ment to supply gas into the European energy system, and the signing in 2010, of the agreement on the construction of "the gas pipeline friendship" with Iran, also known as the "Islamic Gas pipeline", is a clear expression of the Moscow - Tehran Damascus axis.

The Syrian conflict that is ongoing today was triggered over control of the sources, transportation and political leverage inherent in Middle Eastern energy. The effective military, political, economic support granted by Russia and Iran (and their tactical allies China and Turkey) to the regime in Damascus confirms the strategic importance of this axis.

The Moscow - Tehran - Dushanbe - Ishmaelite communities of Central Asia Axis complete the composition of the Russian Strategic Plan in Eurasia, according to the directions set forth by Dughin, who attributed to Iran the role of Central Asia's "Padishah ${ }^{38 "}$ ". The idea of restoring the Islamic Persian Empire nurtures Iran's regional power aims and strengthens her connection with the Russian Federation, regarded by the Iranian nationalists as the providential power to help Persia to regain her lost glory. The "Great Iran" specter in Central Asia should be seen in conjunction with the support given by Moscow to the Damascus - Tehran axis as a Russian negotiation, pressure and control tool of the Persian state and as a

\footnotetext{
${ }^{38}$ King of the kings in ancient Persia.
} 
counterweight to the Turkish neo - Ottoman - ism, Saudi Arabia Wahhab - ism, Western influence and especially to the Chinese influence. In this regard, it should be noted that through "Belt and Road Initiative" ${ }^{39}$, published on the $28^{\text {th }}$ of March, 2015, China became an active major geostrategic player in Central Asia and the Black Sea region, in direct competition with the Russian Federation.

\section{The Tactics}

From the tactical point of view, it outlines the following objectives:

A. Weakening the internal social cohesion followed by initiating and/or maintaining instability in the tangent states to the advanced strategic defense perimeter while preventing/eliminating/reducing competitive power presence in the region in order to embed the targeted countries into the Russian sphere of influence or to transform them into buffer zones.

B. Weakening of the Russian Federation's security ring countries' and the competing powers' responsiveness, while moving global attention from the geopolitical processes involving Russian security ring.

These tactical objectives will be achieved through operations described in the "new generation warfare/ non-linear warfare ${ }^{40}$ " $\left(\right.$ Gerasimov doctrine $\left.{ }^{41}\right)$ as follows:

1. Subversion operations designed to alter the response of the political decision makers involved in countering Russian strategic plans;

2. Diversionary operations (handling/negotiation) aimed to limit the responsiveness of geopolitical competitors;

\footnotetext{
${ }^{39}$ Vision and Actions on Jointly Building Silk Road Economic Belt and 21 st-Century Maritime Silk Road, issued by the National Development and Reform Commission, Ministry of Foreign Affairs, and Ministry of Commerce of the People's Republic of China, with State Council authorization, March 2015, Xinhuanet, http://news.xinhuanet.com/english/china/2015-03/28/c_134105858.htm, accessed at 10.02.2016.

${ }^{40}$ The concept of Non-linear Warfare has been publicly formulated, few days before the Crimeean invasion, by Vladislav Surkov (aka Nathan Dubovitsky), political adviser to Russian President Vladimir Putin. In fact this concept restates the American concept of „,hybrid warfare”. See: Peter Pomerantsev, How Putin is reinventing warfare, Foreign Policy, 05.05.2014, http://foreignpolicy.com/2014/05/05/how-putin-is-reinventing-warfare/, accessed at 07.07.2016.

${ }^{41}$ Publicly presented in 2013, by the Chief of Staff of the Russian Armed Forces, Army General Valeriy Gerasimov Vasilevich in The Value of Science in Prediction, MilitaryIndustrial Kurier, February 27, 2013, in Russian language at: http://vpknews.ru/sites/default/files/pdf/VPK_08_476.pdf and in English language at https://inmoscowsshadows.wordpress.com/2014/07/06/the-gerasimov-doctrine-and-russiannon-linear-war/, accessed at 07.07.2016.
} 
3. Discourage constraint operations by intimidating competing forces;

4. "False flag"/covert operations designed to deceive, to mislead the opponent/public opinion regarding the real identity of the authors;

5. Insurgency - like operations followed by devolution and intervention.

Political subversion operations used both influence agents placed in "key" political places in the targeted state, and influence agents turned into "opinion leaders" who legitimize the political decision of subversive "key politicians" through messages transmitted through the media. For this purpose, are used disinformation/intoxication and propaganda means, following these main topics:

$\checkmark$ undermining the social national cohesion by stimulating inter-ethnic, interreligious, inter-cultural conflict, between social groups, between populations belonging to different age groups, and between elites (cultural, political, military, social) and the general population, etc;

$\checkmark$ undermining the cohesion inside those main competing organizations, NATO and the EU, by divide et impera strategies such as offering preferential treatment and economic advantages to some member states over others;

$\checkmark$ undermining the national morale of a given target country through propaganda, including, emphasizing the destructive capacity of the Russian Army compared to the weak defense capacity of the targeted state;

$\checkmark$ subversion of the national idea and patriotism by using morally compromised influence agents with excessive patriotic speeches or, on the contrary, constantly condemning patriotism as extremist, nationalistic, xenophobic, etc.;

$\checkmark$ undermining the countering of Russian influence networks ("fifth column") through mass-media attacks against responsible institutions in order to discredit their leaders, to decrease the public trust in their professional and moral conduct, or through using key-position influence agents within the judiciary system to block legal procedures;

$\checkmark$ undermining the public trust in the state power institutions such as the military, intelligence services, police, gendarmerie, and the state's political and administrative institutions by supporting and propelling into leading positions compromised individuals, in short, traitors;

$\checkmark$ compromising hostile or unfriendly public personalities while supporting vulnerable leaders.

Diversionary operations (handling/negotiation) aimed to limit the responsiveness of the geopolitical competitors by:

$\checkmark$ translation of the interstate conflict into „law - fare” while blocking any UN resolution condemning aggression, or approving multinational intervention in order to restore peace, for crisis management, humanitarian aid, etc. 
$\checkmark$ splitting the competitors' cohesion through „the carrot and stick” actions such as providing important benefits, including special economic, political, diplomatic, strategic partnership for friendly powers and assessing penalties to hostile ones.

Discourage constraint operations by intimidating competing forces:

$\checkmark$ unpredictable international political behavior that combines ceasefire agreements which are invariably violated with strong attacks on the opponent that are meant to amplify the fears of the ceasefire partners about rising tensions, conflict escalation, and the threat of nuclear weapons;

$\checkmark$ conducting sudden inter-arms widespread joint military exercises, involving local and intercontinental maneuvers that mimic mobilization/attack/invasion of one of the competing powers;

$\checkmark$ alerting strategic forces, advanced placement of the nuclear tactical transport vectors, aerial aggressive patrolling of the surrounding area.

"False flag" operations that:

$\checkmark$ legitimate an aggression;

$\checkmark$ discredit political opponents;

$\checkmark$ include espionage/counterespionage;

$\checkmark$ include pseudo-operations (made by organized groups wearing adverse power military insignia to gather information or performing operations in the adverse field: sabotage, kidnappings, assassinations, terrorist attacks, etc.)

While the true author of "false flag" operations is eventually proven, the suspicions regarding the originator of operation may be viewed within the general conceptual category of "conspiracy theory" benefiting from consistent media/propaganda support that counter or confuse any accusations of guilt.

Insurgency-like operations followed by devolution and intervention:

$\checkmark$ hybrid warfare operations: strong insurgent-like soldiers without national insignia seen in Crimea as "little green men", tactical groups of "volunteers" under the command of the Russian soldiers, such as the situation seen in Ukraine's Donbas Region, training centers and logistic support of insurgents located along a border, cyber-attacks, blocking of military and civilian communications, the destruction of the critical infrastructure, attacks on the national currency, economic extortion or sanctions in parallel with subversive aforementioned operations;

$\checkmark$ administrative takeover of the main institutions by the insurgents followed by referenda in order to legitimate the new leadership. 


\section{Conclusion}

The strategic analysis of the geopolitical processes in the Black Sea region cannot ignore the global domination paradigm that outlines the Russian Federation's foreign policy directions Russia is the main hegemonic power in the region whose national territory coincides with much of ,the North pivot zone" described by the British $19^{\text {th }}$ Century theoretician Halford J. Mackinder. Therefore, the Russian Federation's security imperative is the preservation of her sole control over the security ring comprising the Arctic zone, the Baltic Sea, the Black Sea-Baltic Sea isthmus states, the Danube Delta, the Black Sea, Asia Minor, Armenia, Persia (Iran), Tibet and Mongolia. In this context, the main Russian strategic directions in the Black Sea region aim to:

$\checkmark$ expand the Russian de facto border, her Line of Advanced Defense, to the internal security ring border;

$\checkmark$ maintain the Caucasian and Central Asian security zone as Russia's exclusive sphere of influence;

$\checkmark$ transform and maintain the North-South trans-European corridor, Iran, Afghanistan, Mongolia as buffer zones;

$\checkmark$ distract the attention of the main geostrategic players from the issues regarding the Russian Federation's security ring by initiating/maintaining/escalation of geopolitical processes away from this area;

$\checkmark$ gathering the forces contesting the unipolarity of the international system;

$\checkmark$ generate Euro-Atlantic cohesion cleavage;

$\checkmark$ initiate and /or maintain geostrategic tensions between the major players acting in the vicinity of Russia's own security ring, and the use of their political, diplomatic, economic, financial, military divergences in their own interest;

$\checkmark$ restore the former Soviet sphere of influence through hybrid instruments.

The geostrategic axes used by Moscow to implement these strategic directions in the Black Sea basin are built around common political, economic, strategic interests, positive bilateral histories, and cultural affinities. Therefore, maintaining and enhancing these axes are priorities of Russian foreign policy. It is interesting to note the presence of three categories of countries in these axes:

$\checkmark$ both NATO and EU impactful and decisive member states (Germany, France, Turkey, Spain, Italy, as well as Greece, Cyprus, Bulgaria, Hungary, Czech Republic, Slovakia);

$\checkmark$ former Soviet states (Armenia, Tajikistan);

$\checkmark$ high value geostrategic countries controlled by Russia (Serbia - Russia's foothold in the Balkan Peninsula, Syria - the "hinge" state in the Levantine basin of the Mediterranean, Iran - the pivotal state in the inner ring of security). 
The existence and functioning of these axes, designed to protect the Northern pivot zone security ring, confirm Mackinder's theory as the roots of the Russian strategic thinking, and the "key" that deciphers Kremlin's political behavior. Once this aspect is understood the geopolitical processes initiated by Russia are perfectly predictable. At a tactical level, Russia aims to:

$\checkmark$ weaken the social cohesion inside the targeted states;

$\checkmark$ initiate and/or maintain the instability in the states tangent to the advanced strategic defense perimeter;

$\checkmark$ prevent/eliminate/reduce the presence of the competing powers in the security ring region;

$\checkmark$ weaken the response capacity of countries in the Russian Federation's security ring, and competitive powers;

$\checkmark$ avert the attention of competing powers from the geopolitical processes involving the Russian security ring to other geopolitical zones.

Tactical hybrid ("new generation/non-linear") operations (described in the Gerasimov doctrine), focus on non-military, intelligence and soft power targets considered precursors to a hard-power intervention. It is interesting to notice that Russian tactics are adjusted according to the targeted states' security guarantees. Thus, the EU axes are targeted by subversion, diversionary, intimidating competing forces, and by "false flag" operations while the Euro - Asian axes (Middle East and Ukraine Tactical fields) involve insurgency-type operations followed by devolution and intervention. 